sation system. The addition of 12 elements to those previously determinable in aqueous solution and a general alleviation of chemical interference by the use of hightemperature flames employing $\mathrm{O}_{2}-\mathrm{N}_{2}$ mixtures and $\mathrm{N}_{2} \mathrm{O}$ with acetylene was revealed by J. B. Willis (C.S.I.R.O., Division of Chemical Physics, Melbourne) in a joint paper with M. D. Amos (Techtron, Victoria). In another paper, J. B. Willis stated that examination of atomizer design has resulted in considerable improvement in performance being achieved by precision in construction and by provid. ing means of accurately positioning the capillary. J. V. Sullivan (C.S.I.R.O., Division of Chemical Physics, Melbourne) discussed the construction and performance of high-intensity lamps. The increase in the intensity of the resonance lines has been achieved by exciting the metal atoms, produced by a hollow-cathode discharge with a secondary discharge electrically isolated from the former. He then described a high-intensity lamp which incorporates an additional hollow cathode which selectively modulates the resonance lines and permits the use of low-resolution monochromators for the isolation of resonance lines in complex spectra. W. Slavin (Perkin-Elmer, U.S.A.), in tracing the development of burners, described a design having multiple slots for producing an $\mathrm{N}_{2} \mathrm{O}-\mathrm{C}_{2} \mathrm{H}_{2}$ flame of high temperature and stability by the operation of sheathing flames on each side. Examination of the performance of this burner has shown that good agree. ment with other methods is obtained, that a number of transitions from excited states absorb and that phosphate enhances vanadium absorption. Mrs. J. A. Bowman (C.S.I.R.O., Division of Chemical Physics, Melbourne), in collaboration with J. C. Heerdt (Commonwealth Railways, Port Augusta, South Australia) and J. B. Willis, reported that good agreement could be obtained between atomic absorption measurement on oil dissolved in 2-mothyl-4-pentanone and both atomic absorption and colorimetric results on dissolved ash for $\mathrm{Cu}, \mathrm{Cr}, \mathrm{Fe}, \mathrm{Pb}$ and $\mathrm{Ag}$, but it was agreed in discussion that the greatest hazard in diagnosis of engine breakdown lies in the sampling of the oil. N. J. Marshall (Bureau of Mineral Resources, Canberra) reported success in the extraction of various substituted thiocarbamate complexes of $\mathrm{Cu}$, $\mathrm{Pb}, \mathrm{Ni}, \mathrm{Co}$ and Te into amyl acetate for the determination of these elements, at parts-per-hundred-million levels, in rocks by atomic absorption; and D. C. Bowditch, jointly with J. A. Powell (both of the Australian Mineral Develop. ment Laboratories, Adelaide), that atomic absorption could compete favourably with other means of analysis in the determination of $\mathrm{Cu}, \mathrm{Zn}, \mathrm{Co}, \mathrm{Ni}, \mathrm{Cd}, \mathrm{Mn}, \mathrm{Sb}, \mathrm{Ag}$ and $\mathrm{Bi}$ both at low concentration in geochemical and mill tailing samples and at high concentration in mill feed and product control. After outlining his methods of soil and plant analysis for some 25 major and minor elements by means of flame emission, porous cup spark emission, rotating disk spark emission on a direct reader and chemical concentration followed by cathode layer arc emission (improved by image converter scanning of plates), R. L. Mitchell (Macaulay Institute for Soil Research, Scotland) described, in an invited address, an atomic absorption method for the determination of extractable cobalt at deficiency-levels in soils, stating that considerable gain in sensitivity had recently been achieved by use of a special atomizing systom, tuned a.c. amplifier and recorder read-out.
A successful mass spectrometry seetion was a late addition to the Conference programme. Seven papers were presented; six of these, including an introductory lecture by J. S. Shannon (C.S.I.R.O., Division of Coal Research, Sydney), dealt with structural applications in organic, metal-organic and co-ordination chemistry, and the seventh with an electric quadrupole mass spectrometer (D. Swingler, C.S.I.R.O., Division of Chemical Physies, Melbourne). The structural applications reported included a structural assignment for the complex fungal metabolite sporidesmin $C$, a tentative structure for the cell growth factor 'Zeatin', a characteristic reaction of 2,5-diaryl oxazole systems in which CO and HCN is eliminated (W. D. Crow, J. Hodgkin, R. Hodges, D. Letham and J. S. Shannon), structures for the Schiff Base bisbenzoylacetone-ethylenediimine and its metal chelates, and the mass spectra of $\mathrm{Ph}_{3} M(M=$ $\mathrm{N}, \mathrm{P}, \mathrm{As}, \mathrm{Sb}, \mathrm{Bi}$ ) and rolated compounds (J. S. Shannon) and of macrorungia alkaloids (R. R. Arndt, K. Biemann, A. Jordaan, V. P. Joynt and J. L. Occolowitz (C.S.I.R.O., Division of Chemical Physics, Melbourne). N. Wasada and I. Tsuchiya (Government Chemical Industrial Research Institute, Tokyo), E. Yoshii (Faculty of Pharmaceutical Sciences, University of Toyama, Japan), T. Fukuzumi (Japan Monopoly Corporation) and E. Watanabe (Japan Electron Optics Laboratory) reported on fragmentation patterns and discussed their mechanisms for santonins and their derivatives and also for solanone, an unsaturated branched aliphatic ketone from tobacco leaf. J. L. Occolowitz (Defence Research Laboratories, Melbourne) and J. M. Swan (C.S.I.R.O., Division of Organic Chemistry, Melbourne) described the mass spectra of phosphonic esters R.PO $\left(\mathrm{OR}^{\prime}\right)_{2}$ and dichlorides $R \mathrm{POCl}_{2}$, and emphasized the value of keeping an accurate electron balance in the formulation of ionic equations. General patterns for the decomposition of odd electron (radical) ions and even electron ions were described. In a stimulating discussion of these papers the approach of the organic chemists to the interpretation of mass spectra was criticized as lacking quantitative energy factors; in reply it was maintained that, provided the approach was utilized correctly, there was at present no better method available.

The remaining section of the Conference consisted of four papers on X-ray spectroscopy. D. McKenzie (Australian Iron and Steel, Wollongong, N.S.W.) described the analysis of coals by X-ray spectroscopy, and in a paper by K. Norrish (C.S.I.R.O., Division of Soils, Adelaide) a technique for silicate analysis was described in which the sample was fused with lithium borate glass, with added lanthanum oxide and cast in a penny-shaped disk. Advantages of this technique include durability of sample and uniform background. K. Norrish and C. G. Gurr (C.S.I.R.O., Division of Soils, Adelaide) described an automatic pulse-height analyser for use in $\mathrm{X}$-ray spectrography, and J. B. Swann (University of Western Australia) the energy of electrons scattered by silver with surface contamination.

The sixth Australian Spectroscopy Conference will be held in Brisbane in 1967.
G. C. Barraclough
P. J. BLACK
D. J. DAVID
A. D. E. Pullin
J. S. ShanNon

\title{
BRITISH AID TO DEVELOPING COUNTRIES
}

A WHITE PAPER from the Ministry of Overseas Development *, outlining the work of the new Ministry, describes the policies by which the British Govermment

* Ministry of Overseas Development. Overseas Development: The Work of the Nero Ministry. (Cmnd. 2736.) Pp. 74. (London: H.M.S.O., 1965.) 5s. $6 d$. net. proposes to be guided and the ways in which it hopes to help to meet the needs of the developing countries, without, however, specifying the extent of Britain's aid in particular periods. Successive chapters outline motives and objectives, the pace of overseas development, the transfer of resources and Britain's capacity to help--in 
which the Department of Technical Co-operation had laid firm foundations. However, it does not really meet the criticism which has come from the Overseas Development Institute, or from the Estimates Committee in its tenth report for the session 1963-64. Mr. R. Carr, then head of the Department of Technical Co-operation, had indicated that Britain's contribution, $£ 190$ millions in 1964, would rise to about $£ 220$ millions, and since the White Paper was published it is understood that this figure will probably be inereased to $£ 250$ millions.

The White Paper makes scarcely any reference to the application of science and particularly of research, and this weakness, exemplified notably in the disbandment of the Overseas Research Council, therefore persists. The initiatives in technical assistance which are being taken in the economic services seem a little inadequate. Certainly, it is unfortunate that in a statement on the White Paper in the House of Commons on August 3 the Minister should have been so petulant and inclined to make a party issue of a matter which has the support of all parties and for which Mr. Carr had laid such good foundations. Mrs. Castle said that the levels of expenditure on aid would be contained in the national plan. It was proposed to establish a careers service in the Ministry for a corps of specialists directly employed by the Ministry who would normally be on loan overseas. The Ministry was also setting up an Overseas Service Pensions Fund to provide pension rights for persons serving overseas for which such provision was not at present made.

Much in the White Paper supplements an earlier statement from the Department of Technical Co-operation in 1963, but further chapters deal with the lines of future policy, the new terms of aid, the private sector and the Commonwealth Development Corporation, the manage ment of aid, and with what are deseribed as "new initiatives in technical assistance", including recruitment and voluntary service, economic services, education, training and public health. It is emphasized that the Ministry would like to see it widely accepted in Britain that a professional career should normally include a period of work overseas in a developing country. The Government has decided, therefore, that in fields of recruitment where it is important to ensure that British help is available, the home establish ments of Government departments and public bodies should be strengthened so as to make it possible to release people more readily. Discussions with other Government departments and the University Grants Committee have shown that there is scope for strengthening certain establishments and that the organizations concerned are willing to co-operate. A total of at least 400 posts will be added for this purpose to home establishments, in Government departments, universitios, technical colleges, etc.

On service overseas by volunteers, the White Paper, noting that the number of such volunteers is expected to rise from 1,400 in the autumn of 1965 , to 1,800 in 1966 , points out that it is important to widen the range of work which volunteers are doing and to draw them from wider sections of our society. On the economic services, more economists and statisticians are being supplied for periods of service overseas, directly attached to Goverrments; it is hoped to increase this number by the recruitment measures just described. A survey of British universities is being undertaken to loarn more about the number and type of economists interested in, and available for, work overseas; the supply of such people will be increased by a new Institute of Development Studies in accordance with the recommendation of the Bridges Committee in 1962. Up to 1,000 non-university teachers are to be recruited in 1965 and almost $£ 200$ millions a year has been spent on the supply of teachers under the Overseas Service Aid Scheme alone. The provisions of the Overseas and Development Service Bill will help to increase new recruitment and retain the services overseas of British staff employed other than by Governments. The Commonwealth Teacher Training Bursary Scheme has been stepped up to 500 and will be increased to 550 next year. The number of students and trainees coming to Britain under the Ministry's programme has risen from just more than 2,000 in $1962-63$ to nearly 2,800 in $1964-65$.

Under the terms of aid, the White Paper refers to the decision to make development loans free of interest where appropriate. It is claimed that the new structure under the Ministry of Overseas Development has strengthened Britain's work on aid in various ways and, after detailing the extent of British aid, there is a brief appendix on the organization of the Ministry. The objective of Britain's aid programme is to help developing countries in their efforts to raise standards of living. Its basis is accordingly a moral one, but it is recognized that provision of aid is to Britain's own long-term economic advantage and that she gives aid because, in the widest sense, it is believed to be in her interests to do so as a member of the world community. British or any other aid is most effective where it forms an integral part of a coherent and co-operative effort to implement a well-prepared development plan.

The White Paper is well written and cogently argued. It directs attention to such obstacles to the development of the poorer countries as the shortage of professional and technical personnel, which in many countries had been even more serious than shortage of foreign exchange in inhibiting development. It also notes the difficulties caused by the accelerated growth of population and, as a consequence of economic and demographic trends, a general failure to find productive employment for the labour force. Its silence in regard to scientific research is its outstanding defect, and from this it is apparent how vulnerable some of the proposals are to the incidence of the Government's new measures of restricted expenditure.

\title{
SOLAR MOTION AND SUNSPOT COMPARISON
}

\author{
BY DR. ROBERT M. WOOD* \\ Assistant Director, Research and Development, Douglas Missile and Space Systems Division, Santa Monica, California \\ AND \\ PROF. KARL D. WOOD \\ Aerospace Engineering Sciences Department, University of Colorado, Boulder
}

\begin{abstract}
CEVERAL attempts have been mado to associate the $\checkmark$ position of the planets with the 11-1-year cycle of solar activity ${ }^{1}$. This article presents some preliminary results of a solar dynamic investigation based on classical dynamics. The inertial frame for bodies in the solar system is the centre of mass of the solar system, not the
\end{abstract}

* Mailing address: Dr. R. M. Wood, 530 Swarthmore Avenue, Pacific Palisades, California 90272 centre of the Sun'. It is known that the centre of the Sun can be greater than one solar radius distant from the solar system centre of mass if Jupiter and Saturn are in the same general direction in space ${ }^{3}$. This motion of the Sun with respect to the solar system centre of mass will lead to forces on and in the Sun which vary with time and heliographic position. Although the spatial relationships between the Sun and the solar system centre of mass 